\title{
Modifying Zebu Milk with Focus on Human Health: Opportunities and Challenges
}

\author{
Gama MAS, Lopes FCF and Peixoto MGCD* \\ Embrapa Dairy Cattle, Juiz e Fora, Brazil
}

Submission: February 01, 2019; Published: February 13, 2019

*Corresponding author: Peixoto MGCD, Embrapa Gado de Leite, Rua Eugênio do Nascimento 610, 36033-330, Juiz de Fora, Brazil

\begin{abstract}
Dairy products have been an important source of energy and nutrients in the human diet for centuries. In addition to their well-established basic nutritional roles (e.g. rich source of calcium for bone building and high-quality protein for muscle growth), more recent studies have also reported health-promoting effects of certain fatty acids, proteins and peptides found in milk. The promising results observed in most studies led to several investigations focused on strategies to increase the milk contents of such bioactive compounds. Although much less is known about the milk composition and the potential of farm-level strategies for improving the nutritional quality and functional aspects of milk fat and milk protein in Zebu breeds when compared to taurine breeds under temperate conditions, some progress has been made as described herein. However, further studies in this field are warranted since milk production in many tropical regions around the globe is largely derived from Zebu breeds and their crosses.
\end{abstract}

\section{Introduction}

Although Hippocrates, regarded by many as the "Father of Medicine", had noticed more than two thousand years ago that some foods can have therapeutic effects in his famous quote "Let food be thy medicine and medicine be thy food"), the term "Functional Foods" was first coined only a few decades ago in Japan. The Functional Food Center (FFC) recently defined Functional Foods as "Natural or processed foods that contains known or unknown biologically-active compounds; which, in defined, effective non-toxic amounts, provide a clinically proven and documented health benefit for the prevention, management, or treatment of chronic disease". Traditionally and regularly consumed by different people around the globe, milk and dairy products are currently considered not just nutrient-dense foods, but also a source of several bioactive compounds with beneficial effects on human health [1]. Bovine milk proteins and peptides have shown to elicit numerous positive health effects (e.g. immunomodulation, antimicrobial, anticancinogenic, antiulcerative, cardioprotective, improved muscle recovery and maintenance, etc.), but some milk proteins can also trigger allergic reactions, especially in children and young people $[1,2]$.

Milk is also a source of several health-promoting bioactive fatty acids, some of which not found in substantial amounts, or even absent, in foods other than dairy [3]. On the other hand, milk fat has been considered for decades as detrimental for human health due to its high saturated fat content, but such association has been strongly questioned by several recent systematic reviews and meta-analyses of observational studies and clinical trials. Notewor thy, the milk fatty acid composition can be modified, to a varying extent, by diet manipulation and genetic selection. Overall, the nutritional studies conducted with crosses of zebu and taurine breeds (usually Holstein x Gyr cows at varying genetic compositions) in Brazil show that, similarly to observed with taurine breeds in temperate countries, increased milk contents of some beneficial fatty acids (e.g. rumenic acid, oleic acid, vaccenic acid) can be achieved by feeding the cows on fresh grass (grazing) and by diet supplementation with plant oils rich in linoleic or $\alpha$-linolenic acid (e.g. soybean oil, sunflower oil, and linseed oil). However, it should be noted that the magnitude of the grazing effect varies to a great extent depending on both pasture management and the type of forage grazed by the cows.

Regarding the latter, results from independent studies suggest that cows grazing elephant grass pastures (or fed fresh cut grass) have higher levels of vaccenic and rumenic acid contents in milk fat than cows grazing Brachiaria grass pastures. However, definitive conclusions cannot be drawn in this regard due to the lack of pasture studies properly designed to compare different grasses (i.e. pasture management and other variables known to influence milk fatty acid composition are controlled). Similarly, there is some evidence that cows fed on grass silage present higher contents of rumenic acid in milk fat than those fed on corn silage or sugarcane. However, as previously mentioned for grazing studies, there is also very limited information regarding the potential of different tropical grasses fed as silage to increase the contents of beneficial fatty acids in milk fat from crossbred or Zebu cows 
in Brazil. In this regard, genetic selection of grasses containing high levels of linoleic and $\alpha$-linolenic acid is a promising area of research as these fatty acids are the major precursors for the synthesis of vaccenic and rumenic acid in ruminants.

Although diet is considered the major factor influencing the milk fatty acid composition of cows, the between-cow variation found in several studies where animals were fed on the same diet suggested a genetic influence, which was later reported to be at least in part explained by the occurrence of variants in genes codifying key enzymes involved in milk fat synthesis, such as the stearoyl-CoA desaturase-1 (SCD1) enzyme. For example, studies with Holstein-Friesian cows found moderate heritability values (15$40 \%$ ) in SCD1 indices, indicating the possibility of using artificial selection breeding as a strategy for increasing the concentration of beneficial fatty acids in bovine milk fat [4]. A significant between-cow variation was also observed in our recent study where Gir and Guzera cows were fed on the same diet, and new polymorphisms in the SCD1 enzyme were detected.

Bovine milk proteins and peptides come from blood or mainly from synthesis in the mammary gland, under the genetic codifying of highly polymorphic genes. Some alleles in specific genes such as casein genes are of importance not only to the dairy products processing but also to the obtaining of dairy products for human health niches. However, unlike fat, the modification of milk protein composition only is possible through genetic selection. The A1 $\beta$-casein, a variant of the $\beta$-casein gene found in bovine milk has been associated with allergy and some non-communicable diseases in humans, and studies have been done to increase the frequency of the A2 $\beta$-casein allele in dairy cattle breeds [5] Therefore, the wide screening of zebu breeds for detection of important genetic variants for fat and protein profile as well as studies on their influence on human health became an opportunity to animal sciences [5]. In this sense, genomic methods constitute a promising tool for the development of accurate genetic selection protocols for dairy cattle. Gir and Guzerá zebu breeds, particularly, have been selected in Brazil over the last 30 years for milk production and solids content in breeding programs, but there is limited information on the milk fatty acids, proteins and peptides profile for these breeds. Therefore, possible differences in milk fat and milk protein profile between taurine and zebu cattle breeds will be investigated in future studies.

\section{Conclusion}

Despite some progress made in the last decade, there is still limited information regarding the milk fatty acid composition of cows consuming tropical grasses, which may be, at least in part, attributed to difficulties in analyzing such a complex food matrix as ruminant milk fat. Further studies are necessary to bring new knowledge about the nutritional quality and other functional aspects of milk protein and milk fat, factors contributing to their variation, as well as the potential of nutritional strategies and marker-assisted or genomic selection for improving these traits. Concerning selection, genomic protocols are still expensive, notably when applied on a population scale. There is an increasing market niche for functional foods in the world, which can benefit the whole dairy chain (dairy farmers, industry, and consumers) and the government due to reduced public health costs associated with the treatment of chronic diseases.

\section{References}

1. Mills S, Ross RP, Hill C, Fitzgerald GF, Stanton C (2011) Milk intelligence: Mining milk for bioactive substances associated with human health. International Dairy Journal 21: 377-401.

2. Kaminski S, Cielinska A, Kostyra E (2007) Polymorphism of bovine beta-casein and its potential effect on human health. Journal of Applied Genetics 48: 189-198.

3. Kratz M, Baars T, Guyenet S (2013) The relationship between high-fat dairy consumption and obesity, cardiovascular, and metabolic disease. Eur J Nutr 52: 1-24.

4. Garnsworthy PC, Feng S, Lock AL, Royal MD (2010) Short communication: Heritability of milk fatty acid composition and stearoyl-CoA desaturase indices in dairy cows. Journal of Dairy Science 93: $1743-1748$

5. Egger-Danner C, Cole JB, Pryce JE, Gengler N, Heringstad B (2014) Invited review: overview of new traits and phenotyping strategies in dairy cattle with focus on functional traits. Publications from USDAARS / UNL Faculty. Pp. 1489.

This work is licensed under Creative Commons Attribution 4.0 License DOI: $10.19080 / J D V S .2019 .10 .555776$

\section{Your next submission with Juniper Publishers} will reach you the below assets

- Quality Editorial service

- Swift Peer Review

- Reprints availability

- E-prints Service

- Manuscript Podcast for convenient understanding

- Global attainment for your research

- Manuscript accessibility in different formats

( Pdf, E-pub, Full Text, Audio)

- Unceasing customer service

Track the below URL for one-step submission https://juniperpublishers.com/online-submission.php 